\title{
RELAÇÕES LABORAIS E LIMITES JURÍDICOS AO ACESSO E USO DAS INFORMAÇÕES GENÉTICAS DO EMPREGADO
}

\author{
LABOR RELATIONS AND LEGAL LIMITS ON ACCESS AND \\ USE OF EMPLOYEE GENETIC INFORMATION
}

\section{RELACIONES LABORALES Y LÍMITES JURÍDICOS AL ACCESO DEL USO DE LAS INFORMACIONES GENÉTICAS DEL EMPLEADO}

\author{
Ana Thereza Meirelles Araújo* \\ Vanessa Vieira Pessanha* *
}

1 Introdução. 2 O panorama do estágio atual da informação genética. 3 As relações laborais na contemporaneidade. 4 Os limites jurídicos ao acesso e uso das informações genéticas do empregado. 4.1 A intimidade como limite preliminar. 4.2 Igualdade e não discriminação genética como limites posteriores. 5 Considerações finais. Referências.

\section{RESUMO}

Artigo destinado à análise dos limites jurídicos conformadores do uso da informação genética no âmbito das relações laborais. Como premissa, partiu-se de uma análise panorâmica sobre o acesso e o uso da informação contida no DNA conforme os padrões atuais da Ciência, considerando os pretensos benefícios e os riscos agregados. Como objetivo central da pesquisa, buscou-se identificar as balizas previstas na legislação em vigor que fundamentam a necessidade de contingenciar o uso da informação genética pelo empregador nas relações pré-contratuais, contratuais e pós-contratuais de trabalho. O estudo em voga tem como justificativa a necessidade de sopesar adequadamente a proteção ao trabalhador em condição

* Doutora em Relações Sociais e Novos Direitos pela Universidade Federal da Bahia (UFBA). Mestre em Direito Privado e Econômico pela Universidade Federal da Bahia (UFBA). Professora do Programa de Mestrado em Direito da Universidade Católica do Salvador (UCSal), do curso de Direito da Universidade do Estado da Bahia (UNEB) e da Faculdade Baiana de Direito. Salvador, BA, Brasil. E-mail: <anatherezameirelles@gmail.com>.http://orcid.org/0000-0001-9623-6103

** Doutora em Relações Sociais e Novos Direitos pela Universidade Federal da Bahia (UFBA). Docente da Universidade do Estado da Bahia (UNEB). Pesquisadora Líder do grupo de pesquisa "Trabalho, Globalização e Direitos Fundamentais" (UNEB / CNPq). Membro do Instituto Baiano de Direito do Trabalho (IBDT). Salvador, BA, Brasil. E-mail: <vanessapessanha@ymail.com>. http://orcid.org/0000-0001-9036-5879 
de vulnerabilidade face à possibilidade de que sua informação genética possa ser arbitrariamente acessada e utilizada, culminando na violação de conteúdos constitucionalmente fundamentais como a igualdade e a intimidade. Optou-se pela perspectiva metodológica hipotético-dedutiva, tendo em vista adequar-se melhor ao objetivo apontado, a partir da construção de pesquisa de natureza bibliográfica.

Palavras-chave: Informação genética. Relações laborais. Direitos fundamentais. Intimidade. Igualdade.

\section{ABSTRACT}

An article aimed at analyzing the legal limits that shape the use of genetic information in the context of labor relations. As a premise, it was started from a panoramic analysis of the access and use of information contained in the DNA according to current Science standar$\mathrm{ds}$, considering the alleged benefits and added risks. As a central objective of the research, it was sought to identify the guidelines provided in the current legislation that support the need to contingency the use of genetic information by the employer in pre-contractual, contractual and post-contractual relations of work. The current study has as justification the need to adequately weigh the protection to the worker in a condition of vulnerability to the possibility that their genetic information can be arbitrarily accessed and used, culminating in the violation of constitutionally fundamental contents such as equality and intimacy. It was opted for the hypothetical-deductive methodological perspective, in order to better fit the objective, based on the construction of research of a bibliographic nature.

Keywords: Genetic information. Labor relations. Fundamental rights. Intimacy. Equality.

\section{RESUMEN}

Artículo destinado al análisis de los límites jurídicos conformadores del uso de la información genética en el ámbito de las relaciones laborales. Como premisa, se partió de un análisis panorámico sobre el acceso y el uso de la información contenida en el ADN conforme a los estándares actuales de la Ciencia, considerando los supuestos beneficios y los riesgos agregados. Como objetivo central de la investigación, se buscó identificar las balizas previstas en la legislación en vigor que fundamentan la necesidad de contener el uso de la información genética por el empleador en las relaciones precontractuales, contractuales y post-contractuales de trabajo. El estudio en boga tiene como justificación la necesidad de sopesar adecuadamente la protección al trabajador en condición de vulnerabilidad frente a la posibilidad de que su información genética pueda ser arbitrariamente accedida y utilizada, culminando en la violación de contenidos constitucionalmente fundamentales como la igualdad y la intimidad. Se optó por la perspectiva metodológica hipotético-deductiva, teniendo 
en vista adecuarse mejor al objetivo señalado, a partir de la construcción de investigación de naturaleza bibliográfica.

Palabras clave: Información genética. Relaciones laborales. Derechos fundamentales. Intimidad. Igualdad.

\section{INTRODUÇÃO}

Os complexos estudos realizados no plano da Genética, contemporaneamente, apontam para um conjunto de novas situações que demandam o acompanhamento paralelo do Direito, frequentemente insuficiente, consoante se pode aferir a partir da marcha de encaminhamento do processo legislativo ordinário. Cabe à doutrina, em muitas situações, antecipar reflexões e entendimentos não regulamentados por lei, com o objetivo de aclarar os juristas e, por vezes, as pessoas de uma maneira geral quanto a pontos de fundamental relevância para o desenvolvimento das relações sociais.

O tema em análise parte justamente da ausência de indicação exata quanto aos limites do uso da informação de natureza genética no âmago das relações pré-contratuais, contratuais e pós-contratuais de trabalho, tendo como objetivo central apontar os indicadores responsáveis por contingenciar o uso de tal conhecimento. Pretende-se, então, identificar os fundamentos ético-jurídicos capazes de limitar o uso da informação contida no deoxyribonucleic acid (DNA) no âmbito das relações laborais, descortinando-os como pressupostos constitucionais e inafastáveis.

A evidente relevância do tema apresenta-se, hoje, acentuada pela necessidade de contribuir para a proteção do empregado, reafirmando a sua condição de vulnerabilidade quando o uso da informação genética possa partir de uma decisão unilateral do empregador e culminar em uma forma clara de discriminação.

Como caminho metodológico, optou-se pela perspectiva hipotético-dedutiva, uma vez que foram estabelecidas premissas antecipadas, expostas nos capítulos preliminares, com o fito de, a partir do apontado, identificar, por dedução, os fundamentos jurídicos que limitam a conduta do empregador. Para tanto, centrou-se a pesquisa em fontes estrangeiras e nacionais especializadas.

A divisão epistemológica da pesquisa atentou para a necessidade de esclarecer previamente a conformação do atual estágio do conhecimento da informação genética, com vistas a esclarecer, inclusive, a multiplicidade dos tipos de testes genéticos possíveis de serem realizados na atualidade, ou seja, a dimensão extensiva das formas de acessar esse conhecimento e das várias finalidades correlatas.

Como premissa importante, buscou-se apresentar um panorama atual das relações de trabalho - área de essência complexa pelas demandas valorativas e os reflexos inerentes à sua atuação -, inseridas em um mundo no qual as relações sociais se tornaram mais intrincadas, 
bem como influenciadas por contextos tecnológicos e, agora, advindos da informação genética.

Tais premissas epistemológicas culminaram no desvelamento dos limites capazes de conformar a conduta do empregador no que diz respeito ao acesso à informação genética do empregado. A inexistente disciplina jurídica específica do assunto não desautoriza a identificação de balizas já incontestavelmente presentes na lei constitucional, com plena envergadura para vedar o uso desse tipo de informação de maneira arbitrária. Tem-se a dignidade, como um fundamento primordialmente ontológico, assim como a intimidade e a igualdade na condição de previsões que, incontestavelmente, são capazes de contingenciar a relação em questão.

Iniciando os tópicos de desenvolvimento, será apresentado o contexto atual no que tange às múltiplas possibilidades que o avanço científico proporciona, na atualidade, acerca dos dados presentes no DNA humano.

\section{O PANORAMA DO ESTÁGIO ATUAL DA INFORMAÇÃO GENÉTICA}

Qualquer estudo concernente à possibilidade de delinear um panorama atual a respeito do estágio do acesso e do uso da informação genética parte do Projeto Genoma, que estabeleceu como benefício principal a identificação de doenças hereditárias, tendo como proposta diagnósticos precoces e informações mais precisas que pudessem esclarecer múltiplas questões em torno da patologia. A partir da execução do Projeto, passou-se a uma compreensão mais detalhada dos mecanismos de transmissão das doenças e do acesso à informação contida no DNA para fins preditivos, ou seja, para antever a própria possibilidade de manifestação daquela patologia identificada por meio da perspectiva da probabilidade.

O problema é que conhecer a constituição genética de uma pessoa, por meio da leitura da informação contida no seu DNA, pode descortinar múltiplas consequências, como, por exemplo, a aferição das relações de parentalidade e filiação, diagnósticos precoces baseados em probabilidades de doenças graves e evidências probatórias para aferição de autoria de crimes. Tais possibilidades aparentemente podem ser consideradas benéficas, mas têm o condão de ocasionar violações a direitos constitucionalmente assegurados.

Assiste-se que, no contexto da América Latina, não há muito interesse dos governos em fomentar pesquisas na área genômica, a fim de ter ciência e estabelecer regras precisas sobre a conformação adequada do uso deste tipo de informação. Na América Latina, percebe-se que a leitura do problema parte do atuar consumerista, já que falta conhecimento dos cidadãos em geral para compreender as complexidades do que significa um teste genético (YUNTA; VALDERBENEDITO; LOLAS, 2018). Algumas clínicas simplesmente fornecem o serviço, realizam o teste genético, com custo significativo, porém não se percebe a difusão de um cuidado relevante quanto à reflexão acerca da justificativa e das consequências do seu uso.

A medicina genômica desenvolveu testes genéticos com potencialidade diagnóstica, que permitem conhecer a constituição genética de uma pessoa, com o objetivo de prever, 
diagnosticar e prevenir o desenvolvimento de doenças. Muitos destes diagnósticos são feitos em sede de procriações medicamente assistidas e, se integrados aos cuidados de saúde de uma forma eticamente aceitável, pode-se consentir e perceber o aumento dos benefícios terapêutico e preventivo de doenças genéticas importantes (UGAS, 2007).

Conhecer a estrutura do DNA e suas mutações - associadas à possibilidade de, por intermédio dos testes genéticos, ter acesso à informação sobre a predisposição ou susceptibilidade genética para certas doenças - inaugurou então a Medicina Preditiva (implementada por meio de testes genéticos de análise sanguínea, ou, ainda, por meio de testes preditivos ou pré-sintomáticos). Naturalmente, a possibilidade de antecipar doenças futuras, proposta desta vertente médica, aponta para a ampliação de uma ciência cada vez mais capaz de manter pessoas saudáveis. A prática preditiva corresponde a um novo paradigma da Medicina, que antecipa, em termos probabilísticos, o aparecimento da condição patológica e, em certos casos, o modo como a mesma se manifestará (ZAGALO-CARDOSO; ROLIM, 2005).

Na perspectiva preditiva, é possível, com pequena margem de erro, prever o aparecimento futuro de manifestações de enfermidades diversas a largo prazo. Se o diagnóstico for de predisposição, a previsão poderá ser de extremo interesse para o diagnosticado, que tem a opção de mudar o seu estilo de vida, modificando seu comportamento, seus hábitos e costumes para fins profiláticos, por exemplo. Por outro lado, percebe-se que, se a doença diagnosticada não for curável e nem influenciável pela profilaxia, o valor da informação genética preditiva parece ser consubstancialmente reduzido, já que a antecipada ciência do diagnóstico em nada transformará o curso da patologia (OSSWALD, 2005, p. 20).

Uma das características mais peculiares da informação genética, conforme Carlos María Romeo Casabona, é sua capacidade preditiva:

[...] pues su anticipación puede abarcar incluso enfermedades respecto a las cuales el individuo es todavía asintomático, es decir, cuando ni siquiera está padeciendo la enfermedad o todavía no ha manifestado sus primeros sintomas en el momento en el que se somete a las pruebas analiticas pertinentes (CASABONA, 2002, p. 285).

O referido autor, dando continuidade à sua explicação técnica do tema, afirma:

esta capacidad predictiva es especialmente significativa en relación con las enfermedades monogénicas, de las que es responsable um solo gen deletéreo, bien dominante (basta com que uno de los dos heredados de ambos progenitores sea defectuoso para que la enfermedad aparezca), bien recesivo (sería necesario que ambos progenitores transmitiesen el gen deletéreo para que se manifestase la enfermedad; si sólo lo transmite uno de los padres, el hijo será sano, pero portador de la enfermedad, que podrá a su vez transmitir a sus propios hijos). Pero lo es menos en relación con las enfermedades plurigénicas en las que, además de intervenir varios genes, incluso situados en cromossomas diferentes, es necesaria la concurrencia de otros factores exógenos o ambientales (por ello se conocen como enfermedades plurifactoriales), en ambos casos por mecanismos no bien conocidos en la actualidad y por ello se habla en sentido más propio de susceptibilidad o predisposición para padecer la enfermedad (CASABONA, 2002, p. 285). 
A concretização da medicina preditiva ocorre por meio dos testes genéticos, cuja utilização permitirá identificar os riscos de desenvolver uma enfermidade e se o indivíduo poderá transmitir patologia aos seus descendentes. Atente-se, nesse contexto, à necessidade de compreender as doenças a partir da ótica multifatorial, pois "fatores ambientais, tanto os ligados ao estilo de vida quanto os decorrentes de exposições nos locais de trabalho ou no ambiente geral, têm influência distinta sobre os indivíduos com relação ao risco de determinadas doenças.” (SEGRE; GATTÁS, WUNSCH FILHO, 2002, p. 160).

A informação genética contida na célula humana é reveladora de uma vasta gama de possibilidades em termos de conduta. São múltiplas as manipulações genéticas que podem gerar diferentes situações práticas, mas que, longe de serem apenas benéficas, são propiciadoras de questões de muita complexidade e de difícil compreensão para a maioria das pessoas, o que inclui os juristas, já que não costumam dominar, em essência, os assuntos relacionados à Genética e à Biotecnologia.

A informação genética está contida no conjunto de marcadores ou estruturas moleculares presentes no material genético. Tais dados demonstram um caráter exclusivo e irrepetível, já que o DNA é um atributo singular de cada ser humano. A informação genética então é pessoal, tendo natureza involuntária e característica aleatória, pois não se pode escolher a própria estrutura de composição e combinar antecipadamente quais informações devem estar contidas nessa estrutura. É, ainda, uma informação de natureza geracional, porque traduz relações entre cadeias hereditárias, apontando para determinadas características genéticas (GALLARDO, 2010).

$\mathrm{O}$ acesso à informação contida no DNA pode culminar em práticas que vão desde um simples aconselhamento genético ou diagnóstico embrionário para fins de procriação (terapia gênica) à própria engenharia genética, além de práticas neoeugênicas, que visem tanto a motivações terapêuticas quanto a objetivos segregacionistas ou raciais, bem como de condutas que se concretizem a partir da violação da intimidade e da identidade genéticas, quando do menosprezo do consentimento do interessado.

Juan María Martínez Otero, em artigo publicado no ano de 2017, afirma que, embora o Direito tenha regulado o uso específico da Genética por décadas - como testes de paternidade, testes de DNA em processos criminais ou formas de diagnóstico pré-natal -, pode-se perceber que a extensão gradual dos testes genéticos convida a uma reflexão cuidadosa sobre o possível impacto desses testes nos direitos fundamentais das pessoas, inclusive considerando diferentes dimensões. $O$ escopo da informação revelada é, certamente, limitado e destinado a circunstâncias muito específicas. Porém, o refinamento das técnicas expandiu consideravelmente esse escopo e a confiabilidade dos mesmos, enquanto reduziu substancialmente seu custo. Assim, pode-se testemunhar uma rápida expansão dos testes, recursos genéticos incentivados internacionalmente por empresas que, além do argumento da saúde, oferecem seus serviços de diagnóstico genético com um propósito fundamentalmente comercial, superando qualquer horizonte de motivação terapêutica (OTERO, 2017, p. 236). 
Prossegue o autor apontando classificação atualizada sobre os testes genéticos aplicados nos dias atuais. Primordialmente, indica os testes usados antes da concepção e do nascimento, bem como logo após o nascimento. Os testes de caráter pré-matrimonial e pré-concepcional oferecem informações aos futuros pais sobre a probabilidade de transmissão de uma doença genética para seus descendentes. Tais testes são especialmente úteis para prevenir a transmissão de doenças produzidas por genes recessivos, que, embora não se manifestem nos pais, podem fazê-lo nos descendentes. Os testes pré-natais, realizados no embrião ou no feto, permitem saber se estes possuem certas anomalias ou doenças, como síndrome de Down ou espinha bífida. Os testes neonatais e pediátricos que podem ser estabelecidos pelas autoridades de saúde têm como objetivo principal fazer um diagnóstico de certas patologias, podendo oferecer uma resposta rápida e eficaz, além de permitirem a obtenção de informações de natureza epidemiológica e estatística, úteis para direcionar mais políticas de saúde pública adequadas (OTERO, 2017, p. 237-238).

Ao explicar os possíveis testes genéticos hoje realizados em adultos, esclarece preciosamente a sua tipologia, considerando aspectos relacionados à finalidade. Os testes clínicos são exames solicitados para fins médicos, normalmente quando verificados os primeiros sintomas de uma patologia ou quando a história familiar permite apontar para tal incidência. Esses testes podem revelar a existência de uma doença já instaurada, o fato de que o indivíduo irá sofrer dessa doença no futuro, ou, ainda, que há certa probabilidade de sofrer disso (OTERO, 2017, p. 238).

O teste farmacogenético, semelhante aos clínicos, visa melhorar a eficácia da medicação e evitar efeitos colaterais. Seu resultado pode ser decisivo para escolher a medicação mais apropriada, a posologia, bem como ponderar reações adversas ou falta de resposta a um determinado medicamento. Os testes com fins de pesquisa são realizados no âmbito de uma investigação científica, portanto não têm como objetivo principal nem o diagnóstico nem o tratamento, mas o avanço no conhecimento do genoma humano. O teste solicitado pelas companhias de seguros visa cumprir a política de avaliar o potencial do risco das pessoas que estão cobrindo. $O$ resultado deste estudo, a partir das probabilidades de que o risco coberto seja materializado, é oferecido a cada cliente com um preço personalizado para o seu seguro. Os testes no local de trabalho são realizados em trabalhadores ou candidatos a fim de proteger de terceiros a saúde ou o interesse do trabalhador. Há também os testes forenses, geralmente relacionados a um processo judicial, e, ainda, o teste solicitado pelo consumidor, categoria relativamente nova de teste genético, com o objetivo de obter informações médicas sobre o estado de saúde presente ou futuro, tomando decisões sobre estilo de vida (como o desenvolvimento de dietas personalizadas, por exemplo) e sendo sua acessibilidade direta aos consumidores - ou seja, sem demandar a prescrição de um profissional de saúde ou uma ordem judicial que os justifique (OTERO, 2017, p. 238-239).

Acrescenta o autor, ainda, os testes genéticos em restos mortais de pessoas falecidas, com o objetivo de identificar as vítimas de um acidente ou tentar determinar a identidade 
do falecido. Também podem ser praticados para verificar a causa da morte ou para realizar testes de paternidade post mortem. Registra, por fim, o autor, que outras classificações podem surgir a partir das demandas em torno das suas finalidades e do consentimento dos sujeitos envolvidos (OTERO, 2017, p. 239).

Avaliar o conteúdo de um DNA humano, seja para fins de aconselhamento procriativo, seja para fins de testes ou diagnósticos genéticos, aponta para a necessidade de atentar quanto a aspectos até então desconhecidos pragmaticamente. A Genética não tem respostas objetivas para conduzir o futuro das pessoas, portanto precisa ser razoavelmente utilizada e interpretada, na medida em que revela um grande potencial para segregar e discriminar indivíduos da mesma espécie.

Assim, deve-se observar o fato de que o desvelamento do conteúdo do DNA, mesmo com sua dimensão promissora, também tem como consequência a necessidade de delinear, do ponto de vista ético e jurídico, quando e como essa informação deve e precisa ser utilizada.

Apresentados esses dados científicos relevantes para a proposta da pesquisa, seguem algumas linhas acerca das relações de trabalho no contexto atual.

\section{AS RELAÇÕES LABORAIS NA CONTEMPORANEIDADE}

O trabalho é considerado elemento intrínseco à vida. Em diversos espaços sociais, a pessoa é inicialmente conhecida e/ou reconhecida pela atividade laboral que desenvolve, muitas vezes antes mesmo de que se pense sobre outros elementos de sua existência.

Arendt $(2015$, p. 122) trata da relação entre trabalho e vida de maneira objetiva e natural: "tudo o que o trabalho produz destina-se a alimentar quase que imediatamente o processo da vida humana, e esse consumo, regenerando o processo vital, produz - ou antes, reproduz - nova 'força de trabalho' de que o corpo necessita para seu posterior sustento."

Em que pese o trabalho não seja algo novo, as relações de trabalho vêm se renovando com o passar do tempo, pela necessária adaptação às demandas que passam a existir e aos anseios da sociedade.

Uma das mudanças que vêm sendo experienciadas na área são as diferentes formas de vislumbrar a própria ideia de subordinação jurídica, que sempre foi um pilar indispensável à caracterização das relações de emprego. Com o advento das inovações de natureza tecnológica, a multiplicidade de maneiras de prestar o serviço só vem crescendo, fato que demanda não apenas disciplina específica para esses casos, como também o alargamento do conceito de subordinação, elemento clássico e imprescindível nas relações laborais.

O critério de dependência econômica passou a ganhar cada vez mais relevância, em detrimento da ideia rígida anterior (circunscrita à obediência direta do empregado). Nesse sentido, manifesta-se Machado (2009, p. 42): "para os trabalhadores, a nova noção de subordinação permitiu que o contrato de trabalho não somente remetesse automaticamente à proteção social, mas se afirmasse a partir da situação de fato." 
O novo modelo de ilação entre empregado e empregador observa, destarte, as tendências naturais da contemporaneidade, fazendo o Direito do Trabalho caminhar no sentido de não só perceber que as mudanças sociais existem, mas, principalmente, assumir o papel de regular a vida em sociedade de maneira mais próxima das demandas atuais. Vale registrar que, apesar das transformações, é inegável a necessidade de cuidado com a classe trabalhadora, que persiste sendo o foco principiológico da área juslaboral - mesmo em tempos de alterações legais de cunho neoliberal.

Seguindo raciocínio semelhante acerca da atualidade, vale ler as palavras de Montanhanha $(2014$, p. 71):

O discurso da automação traduz uma forma de dominação. Com a aquisição de bens tecnológicos pelos empresários, os trabalhadores atualmente encontram na automação um fator de perda de postos de trabalho e de consequente desemprego. Clama-se pela qualificação dos trabalhadores, como alternativa para reinserção no mercado de trabalho. Mas teriam os trabalhadores acesso e capacidade para acompanhar a velocidade dos avanços tecnológicos que estão em curso e que podem exterminar sua possibilidade de conseguir um novo emprego? Onde estariam a autonomia e a independência do ser vivo? Por essa razão, o papel do sistema dos direitos fundamentais é indispensável para conferir legitimidade ao exercício dos poderes na dinâmica das relações de trabalho subordinado.

Pensar em relações laborais na contemporaneidade, conforme mencionado em linhas anteriores, inevitavelmente remete à evolução tecnológica e seus efeitos no mundo do trabalho.

Uma das vias de possível tratamento do tema seria a percepção do dever fundamental que tem o empregador nesse processo, com a necessidade de auxiliar nesse imperativo de qualificação profissional do empregado (PESSANHA, 2015), tendo em vista, dentre outros pontos, as implicações bastante perceptíveis da noção de aldeia global. No mesmo sentido, o Estado também deve oportunizar o preparo da mão de obra para as exigências do mercado na atualidade.

O desemprego estrutural é uma realidade que vem avançando em todo o mundo e também está diretamente ligada ao cenário atual que envolve as relações de trabalho. Alguns dos caminhos para auxiliar na resolução dessa tarefa passam justamente pelo investimento na qualificação dos trabalhadores, valorizando sua atuação e a grande contribuição que podem trazer para esse contexto, estando devidamente preparados para exercer as tarefas que se fizerem necessárias.

Cassar (2010, p. 11) indica que "[...] a dinamização do mercado mundial, o avanço tecnológico e científico, a revolução na comunicação, substituição do homem pela máquina automatizada e outros fatores impactam de forma negativa os países de economia mais frágil [...]." A referida autora registra também que a globalização e seus efeitos nas relações de trabalho "[...] abalam [...] níveis salariais, exigem mão de obra cada vez mais especializada, aumentam o índice de desemprego, conduzindo à desintegração social.” (CASSAR, 2010, p. 11).

Percebem-se, portanto, como fio condutor desse discurso, as inúmeras e profundas mu- 
danças, que vêm cada vez mais se acentuando na atualidade, em decorrência do fenômeno de integração mundial e dos avanços tecnológicos. Vale mencionar que o tema central do presente estudo também está intimamente ligado aos avanços na área da medicina (conforme explicitado no tópico anterior), oportunizando, dentre outros fatores, conhecer cada vez mais a fundo os detalhes do patrimônio genético de cada pessoa, fato que pode gerar uma vulnerabilidade ainda maior dos trabalhadores nessa era de difícil acesso aos postos de trabalho e permanência nestes.

Em total conexão com essa análise, aparecem os contextos de colapso econômico. Lopez (2001, p. 37) registra o quão importante é a estabilidade do sistema econômico para o modelo clássico de regulamentação trabalhista. $\mathrm{O}$ acirrado debate que ocorre fora desse padrão é uma constante histórica (o autor menciona a crise da década de 1970 na Espanha), com alta capacidade de retrocesso quanto aos direitos sociais em circunstâncias de redução da margem de lucro dos detentores dos bens de produção. O modus operandi vem se mostrando extremamente semelhante, mesmo em lugares e épocas diferentes.

Por fim, em um tópico de panorama sobre as relações laborais na contemporaneidade, é interessante destacar que, especialmente no cenário nacional, o conjunto de regras que disciplina o campo juslaboral também vem passando por diversas mudanças nos últimos tempos (fundamentadas justamente no momento de crise econômica), como é possível citar a Reforma Trabalhista (Lei n ${ }^{\circ}$ 13.467/2017), cuja repercussão atinge mais de 100 (cem) pontos da Consolidação das Leis do Trabalho (CLT), principal norma infraconstitucional responsável por regular as relações jurídicas dessa natureza. Sem dúvida, novos tempos vêm sendo observados nessa área do conhecimento. Esse fato, aliado à evolução das pesquisas no que tange à informação genética, reforça a relevância de tratamento de temas como o proposto na pesquisa em voga, uma vez que se percebe uma conjuntura de ampliação da vulnerabilidade do trabalhador.

A seguir, buscar-se-á compreender as possibilidades de conformação entre as premissas do tema apresentadas até então no presente artigo.

\section{OS LIMITES JURÍDICOS AO ACESSO E USO DAS INFORMAÇÕES GE- NÉTICAS DO EMPREGADO}

A limitação ao uso de qualquer informação de natureza genética de uma pessoa advém de matéria de natureza constitucional. Se a informação genética revela um conteúdo irrepetível - ou seja, exclusivo de cada pessoa -, compõe parte da identidade pessoal deste indivíduo. Enquanto parte da identidade pessoal, seu teor é de titularidade de cada ser humano, o que desautoriza qualquer uso irresponsável e sem consentimento comprovado.

Outros limites estão diretamente relacionados ao acesso e uso de tais informações, emanando também da ordem constitucional, como o direito à intimidade e o direito à igualdade, este desdobrado na perspectiva da vedação a qualquer tipo de discriminação. 
Acrescente-se, como primordial, que a Constituição Federal de 1988 determina o princípio da dignidade humana como um dos fundamentos do Estado Democrático de Direito, vinculando a discussão em tela a um comando ontológico imanente à existência do ser humano. A dignidade antecede, em essência, a ideia de ser meramente um dispositivo normativo e transcendente à letra fria da norma de maneira a se comportar como elemento considerável a toda e qualquer situação que aponte para o vilipêndio de direitos fundamentais.

Como preliminar relevante, vale registrar que a eficácia dos direitos fundamentais nas relações privadas é amplamente admitida, como explica Alexy (2011, p. 524): “[...] as normas de direitos fundamentais também têm influência na relação cidadão/cidadão. [...] esse efeito perante terceiros, ou efeito horizontal, é extremamente útil para deixar claro o efeito dos direitos fundamentais e das normas de direitos fundamentais no sistema jurídico."

Sombra (2011, p. 36) lembra elemento importante nesse contexto: "[...] a eficácia dos direitos fundamentais sofre contornos significativamente tênues, porquanto cada indivíduo se encontra, por inúmeras ocasióes, na condição simultânea de violador e titular de direitos fundamentais." Em que pese a condição naturalmente peculiar, o reconhecimento da aplicação dos direitos fundamentais nessas situações também é defendido pelo referido autor.

Nas palavras Sarlet (2015, p. 392), "para além de vincularem todos os poderes públicos, os direitos fundamentais exercem sua eficácia vinculante também na esfera jurídico-privada, isto é, no âmbito das relações jurídicas particulares." O contrato de emprego e seus efeitos apresentam, notadamente, a realidade de uma relação jurídica que não tem o Estado como uma das partes do negócio jurídico pactuado e, assim sendo, com tratamento voltado para essa perspectiva.

Há um tempo considerável também a doutrina já vem defendendo a necessidade de compreender que "o poder intra-empresarial é uma relação jurídica contratual complexa, qualificada pela plasticidade de sua configuração e pela intensidade variável do peso de seus sujeitos componentes." (DELGADO, 1996, p. 191). Em que pese a subordinação intrínseca às relações de emprego, a complexidade da relação jurídica em si não permite uma tomada de posição a priori já no sentido de sempre garantir livre atuação ao empregador em nome dos poderes que este exerce, demandando uma avaliação mais cuidadosa em cada questão que é posta a exame, como é o caso do estudo em tela.

Firmadas as bases de aplicação, em seguida serão explicitados os principais direitos relacionados à questão do acesso e uso das informações genéticas do obreiro pelo empregador.

\subsection{A INTIMIDADE COMO LIMITE PRELIMINAR}

Percorrendo o iter necessário para a construção dos limites de acesso e uso das informações genéticas do empregado, aparece como impedimento inicial o direito à intimidade.

Segundo Cunha Júnior (2015, p. 573), "a intimidade é a vida secreta ou exclusiva que alguém reserva para si, sem nenhuma repercussão social, nem mesmo junto à sua família, aos seus amigos e ao seu trabalho." 
Trata-se de um reconhecido direito fundamental, com status mais específico de direito da personalidade, uma vez que diz respeito à esfera intrínseca à própria noção de humanidade e vida em sociedade.

Seus reflexos reverberam também no mundo do trabalho e Romita (2014, p. 318) explica sua condição de direito negativo (a ser preservado): "a intimidade é um direito da personalidade do indivíduo e, portanto, direito do trabalhador no âmbito da relação de emprego. [...] significa assegurar a proteção a certos aspectos da vida íntima da pessoa, que tem o direito de resguardá-los da intromissão de terceiros."

No mesmo sentido, discorre Alvarenga (2013, p. 114): "a intimidade atua como uma espécie dos direitos da personalidade do trabalhador e compreende um direito que lhe é assegurado de não ter a revelação de certos aspectos pessoais da sua intimidade e dos seus sentimentos e/ou pensamentos a terceiros."

Observa-se, nesse contexto, o direito de ter blindados fatos e informações de sua vida íntima que não se deseja compartilhar. Vale ressaltar que os dois autores mencionados nas linhas anteriores já aplicam essa noção geral dos direitos da personalidade diretamente ao âmbito das relações de trabalho, robustecendo o argumento de que a intimidade não perde força ou se relativiza diante desse tipo de relação jurídica.

Gediel (2010, p. 149) já registrava que "a cultura juslaboralista contemporânea tem-se mostrado sensível [...] [às] transformações sociais recentes e [...] a Justiça do Trabalho brasileira vem percebendo, com acuidade, as matizes constitucionais e a especificidade dos direitos fundamentais dos trabalhadores."

Sem dúvida, muitas têm sido as mudanças e evoluções de estudos nas mais diversas áreas que afetam diretamente o exercício dos direitos fundamentais dos trabalhadores. $\mathrm{O}$ tema ora em estudo demonstra bem a ocorrência desse fenômeno.

Como preconiza Viana (2013, p. 81), "a informação genética faz parte da esfera privada pessoal." Para o autor, "[...] sustenta-se que as informações genéticas preditivas fazem parte da vida íntima, sublinhando um grau de proteção maior [do que a noção de privacidade], que, em última instância, advém das próprias especificidades dos dados preditivos." (VIANA, 2013, p. 82).

O enquadramento do conteúdo técnico do DNA do trabalhador, nessa seara, é defendido pela doutrina como sendo de foro íntimo e, assim, destinatário de proteção especial pelo sistema jurídico. Percebe-se, dessa maneira, a relevância, do tema e, sobretudo, de suas implicações práticas na vida do ser humano - em especial, quando avaliado na condição de empregado (ou aspirante à vaga).

Meireles (2004, p. 162) desenvolve, em sua obra, a violação da intimidade nos contratos de emprego tanto na modalidade de prática abusiva (como "[...] ato unilateral, praticado por um contratante independente da vontade do outro contraente") quanto como cláusula abusiva (quando se trata de "[...] fruto de um acerto negocial, ainda que viciado"). Essa distinção merece destaque, especialmente no âmbito do Direito do Trabalho, uma vez que se trata de um 
contrato normalmente de adesão, ou seja, em que não há espaço para discussão de suas cláusulas. Dessa forma, ainda que tenha assinado o contrato contemplando registro no sentido de autorizar o acesso e o uso de suas informações genéticas, é possível caracterizar tal prática como transgressora de direitos fundamentais - aqui, mais especificamente, do direito à intimidade.

O referido autor (MEIRELES, 2004, p. 174) indica algumas hipóteses em que seria permitido realizar exames - como nos casos em que há necessidade de constatar a capacidade para exercício do trabalho (atingindo os atletas profissionais, por exemplo) ou riscos à saúde (para pilotos de avião ou motoristas, por exemplo, avaliando a propensão de ataque cardíaco), bem como exames admissionais comuns -, opções em que não é possível enquadrar a investigação genética do empregado, tendo em vista essa última hipótese também abarcar questões para além da aptidão imediata ou do risco em virtude da atividade laboral. Ou seja, na hipótese dos testes genéticos, restariam não contemplados os fundamentos das exceções apresentadas, procurando estabelecer elementos que ultrapassam significativamente uma verificação em medida de razoabilidade para o exercício da profissão.

Como registra Nascimento (2009, p. 88), "o direito à intimidade, por estar consagrado expressamente no texto constitucional, é oponível ao empregador, devendo ser respeitado, independentemente do fato de o trabalhador figurar numa relação de emprego." Pontua-se, por conseguinte, tanto a necessidade de observância do referido direito nas relações de trabalho como um todo (não só nas relações de emprego) quanto no período que antecede a contratação em si (a conhecida fase da pré-contratação), momento em que o respeito a essa norma em estudo também já deve ser assegurado.

Já estabelecendo o elo entre o presente subtópico e o próximo, Viana (2013, p. 88) afirma que a carga genética da pessoa, "além de trazer informações [...] também sobre o futuro, pode ser considerada como uma das esferas mais íntimas do homem, já que o seu conhecimento por terceiros pode levar a estigmatizações e discriminações."

Na sequência, tratar-se-á da isonomia e do direito à não discriminação genética na condição de balizas também indispensáveis na análise que perpassa o tema em sua aplicação às relações de emprego.

\subsection{IGUALDADEENÃO DISCRIMINAÇÃO GENÉTICA COMOLIMITES POSTERIORES}

O conhecimento ampliado da carga genética de pessoas pode trazer como consequência diferentes discriminações. Embora irmanados pelo sentido de dignidade, inerente a toda e qualquer pessoa, a herança genética da espécie humana aponta para parâmetros distintos. Como resultado, há pessoas com códigos genéticos muito diferentes, compondo um plexo de características, qualidades, defeitos e doenças que se manifestam objetivamente. Considerando essa realidade, o Direito deve esforçar-se para fortalecer a igualdade, pugnando por afastar qualquer fundamento que seja no sentido de ocasiosar uma possível discriminação por causa genética (OTERO, 2017, p. 242). 
Para Lima Neto (2008, p. 62), a discriminação genética manifesta-se como um "reducionismo genético da pessoa humana, que passa a ser considerada exclusivamente como um objeto de resultado da ação do conjunto de genes que possui, os quais têm a probabilidade de causar doenças e determinar comportamentos [...]."

Aplicada às relações de trabalho, existe a perspectiva de se pensar, então, o uso desse tipo de informação como possibilidade preliminar de "simplificar" o processo de recrutamento de empregados, fazendo com que fossem dispensados entrevistas e formulários. Esse cenário, contudo, pode gerar repercussões jurídicas e sociais extremamente significativas. "O resultado de um exame genético será o curriculum vitae ou o passaporte para uma vida excluída da sociedade ou de certos grupos dela", de modo que "o uso que se pode dar ao conhecimento das características do genoma humano pode criar a figura do 'trabalhador perfeito', que tenha todas as predisposições genéticas para o bom desempenho de determinada função", tornando "os demais candidatos inaptos ou indesejáveis para aquele cargo ou empresa” (MYSZCZUK; MEIRELLES, 2009, p. 1180).

A admissibilidade dos testes genéticos tem sido questionada no contexto de relações trabalhistas, tendo em vista a possibilidade de que o empregador faça uso discriminatório dos seus resultados.

Em relato especializado sobre o assunto, Otero (2017) destaca a existência de alguns tipos de testes. O primeiro tipo de teste é o destinado a identificar predisposições de natureza genética que causam hipersensibilidade a certas substâncias existentes no local de trabalho. Assim, sempre com o consentimento do trabalhador, os testes podem ser realizados, já que o objetivo é proteger a saúde do funcionário ou candidato ao cargo. A justificativa para o teste não é baseada preliminarmente no consentimento do candidato ou trabalhador, mas nas exigências objetivas de saúde que um determinado trabalho ou cargo exigem. Também seria possível justificar esses teste para aqueles trabalhos que implicam uma grande responsabilidade, como o controlador de tráfego aéreo, piloto ou membro das Forças de Segurança do Estado. Assim, se o objetivo do teste é detectar uma patologia que pode afetar seriamente interesses de terceiros, o teste está justificado. No entanto, nestes dois casos, que são verdadeiramente excepcionais, os resultados disponibilizados ao empregador devem ser os mais restritos possíveis. Outro tipo de teste, neste caso discriminatório, é aquele que tende a detectar doenças e predisposições genéticas do empregado não ligadas ao seu trabalho atual. São testes realizados por empregador, a fim de evitar declínios na produção ou prever uma possível licença médica com custos para a empresa. Resta, aqui, um exemplo claro de discriminação genética, que penaliza o trabalhador, seja para que o mesmo não alcance a contratação, para que não desempenhe determinadas funções ou para que seja contratado tendo como base exclusivamente o conteúdo do seu código genético (OTERO, 2017, p. 245).

Esse posicionamento coaduna com informação apresentada no tópico anterior e reflete a preocupação de enquadrar adequadamente situações distintas, a fim de evitar o alargamento de interpretações em prejuízo dos relevantes preceitos de proteção que são aplicáveis ao empregado. 
A Constituição Brasileira traz, expressamente, garantias de isonomia de tratamento aos trabalhadores e direito a não discriminação no trabalho, conforme se extrai dos artigos $5^{\circ}$ e $7^{\circ}$, incisos XXX, XXXI e XXXII, in verbis:

Art. $5^{\circ}$ - Todos são iguais perante a lei, sem distinção de qualquer natureza, garantindo-se aos brasileiros e aos estrangeiros residentes no País a inviolabilidade do direito à vida, à liberdade, à igualdade, à segurança e à propriedade, nos termos seguintes:

$[\ldots]$

Art. $7^{\circ}$ São direitos dos trabalhadores urbanos e rurais, além de outros que visem à melhoria de sua condição social:

$[\ldots]$

XXX - proibição de diferença de salários, de exercício de funções e de critério de admissão por motivo de sexo, idade, cor ou estado civil;

XXXI - proibição de qualquer discriminação no tocante a salário e critérios de admissão do trabalhador portador de deficiência;

XXXII - proibição de distinção entre trabalho manual, técnico e intelectual ou entre os profissionais respectivos; [...] (BRASIL, 1988, on-line).

Disso decorre que a proteção do trabalhador contra práticas discriminatórias advém do texto constitucional, que traz, como direito fundamental do trabalhador, a vedação de toda e qualquer forma de discriminação ilícita. Infraconstitucionalmente, a não discriminação foi abordada pela Lei n ${ }^{0}$ 9.029, de 13 de abril de 1995, "que proíbe a adoção de qualquer prática discriminatória e limitativa para efeito de acesso à relação de trabalho, ou de sua manutenção, por motivo de sexo, origem, raça, cor, estado civil, situação familiar, deficiência, reabilitação profissional, idade, entre outros." (BRASIL, 1995, on-line). Acrescente-se que, "ao dispor a expressão 'entre outros' o legislador abriu campo para todas as possíveis formas de práticas discriminatórias e limitativas”, o que culmina no fato de que a lista de possibilidades discriminatórias apontadas é meramente exemplificativa (GUNTHER; PEREIRA, 2017, p. 172-173).

O Projeto de Lei no 4.610 de 1998, que tramita há vinte anos no Congresso, traz diversas preocupações quanto à divulgação dos resultados de testes genéticos, define crimes de discriminação genética e estabelece regras para a realização de testes preditivos de doenças genéticas. Como pontos mais relevantes, registra questões quanto à limitação, negação ou descontinuação das coberturas de seguros de qualquer natureza depois de analisado o perfil genético do possível segurado; aspectos quanto à recusa, negação ou impedimento de matrícula do aluno em estabelecimento de ensino público ou privado, a partir de informações genéticas; pontos quanto à recusa, negação ou impedimento de inscrição em concursos públicos ou outra forma de seleção com base em informações genéticas, ou, ainda, elementos quanto ao acesso ou permanência no emprego, cargo ou função, seja esta na Administração Pública ou entidade privada; e, por fim, preocupa-se também com o sigilo de tais informações (GUNTHER; PEREIRA, 2017, p. 173- 174).

Nas palavras de Alvarenga (2013, p. 219), "a análise do código genético do candidato ao emprego representa, assim, prática de ato de discriminação na seara laboral.” Na visão 
da autora, "[...] nem mesmo com a concordância do trabalhador é possível a exigência de realização de exames genéticos.” (ALVARENGA, 2013, p. 219).

$\mathrm{O}$ jus variandi característico da relação de emprego pode concorrer para o exercício da discriminação nesse âmbito, uma vez que o empregador tem, por exemplo, o direito de escolher quem deseja que trabalhe (tanto em relação ao início quanto no que tange à permanência) em seu empreendimento (ALVARENGA, 2013, p. 147). É necessário, contudo, haver limites para esse poder intrínseco ao empregador.

Ao abordar a diferença entre tratamento desigual e tratamento discriminatório, Lima (2011, p. 25) é bastante direto: "[a palavra discriminação] quebra a complexa e fundamental norma de tratamento igual entre os seres humanos, a qual, muitas vezes, é vislumbrada como expressão da própria justiça." O autor explica, em seguida, que "o ato discriminatório traz consigo uma distinção ilegítima que promove diferenças entre duas pessoas ou entre dois grupos" (LIMA, 2011, p. 25).

Resta clara, portanto, a necessidade de cuidado especial nessa área, tendo em vista a viabilidade de ser configurada notória discriminação a partir do acesso e uso das informações genéticas do empregado, podendo ocorrer tal tratamento de maneira a impedir a própria contratação, inclusive.

Viana (2013, p. 85), ao apresentar as razões para não utilização da informação genética no âmbito laboral, levanta algumas questões relevantes, dentre as quais se registra aqui, pela relação temática, o caráter meramente probabilístico das predisposições genéticas. Ele lembra que "o fator genético é importante, mas não absolutamente determinante. Faz-se necessária a conjugação de diversos elementos para produzir-se o resultado da afecção." (VIANA, 2013, p. 85).

Romita (2014, p. 366), por seu turno, também aborda especificamente a questão ao tratar de discriminação nas relações laborais: "durante o processo de seleção de candidatos a emprego, a discriminação pode caracterizar-se, até mesmo, por meio da análise da codificação genética do candidato, a fim de averiguar [...] se é portador de alguma anomalia genética [...]." O posicionamento do autor é explícito ao indicar que "inexiste no ordenamento jurídico brasileiro norma que vede essa conduta do empregador, mas ela é certamente injurídica por força do princípio da vedação da discriminação.” (ROMITA, 2014, p. 366).

Não há como negar que o acesso e o uso das informações genéticas do empregado - ou candidato à vaga de emprego - podem funcionar como mecanismos de seleção baseados nos elementos encontrados em investigação dessa natureza. Estaria concretizada, assim, uma seleção de funcionários tomando como parâmetro a discriminação genética e tal postura, como se vem demonstrando ao longo do texto, passa ao largo de um comportamento que encontra respaldo jurídico - e até mesmo certeza científica de ocorrência, frise-se.

Ao tratar sobre utopia na era da incerteza, Bauman (2007, p. 100) afirma que "[...] sonhamos com um mundo no qual possamos confiar e acreditar. Um mundo seguro.” Pensando acerca essa análise, é possível afirmar que os direitos à intimidade, igualdade e não 
discriminação estariam protegidos com a autorização de acesso e uso das informações genéticas dos empregados? O questionamento proposto parece indicar um ponto de reflexão dos mais valiosos, uma vez que remonta à necessidade de atenção especial à forma de tratamento a ser destinada à questão jurídica ora em análise, especialmente quanto às suas repercussões jurídicas baseadas em aspectos probabilísticos. Esse fato pode findar ampliando a propagação dos efeitos dessa era de incerteza(s) - e o mais grave: em prejuízo direto à vida (e suas múltiplas facetas de atuação) do trabalhador.

\section{CONSIDERAÇÕES FINAIS}

O trabalho humano, mesmo no contexto de evolução tecnológica e de investigação genética, continua sendo responsável, em uma parcela extremamente significativa das vezes, pela subsistência do empregado e/ou da sua família. Esse fator, por si só, já indica a relevância de avaliação do tema sob um olhar mais cuidadoso, especialmente tendo em vista os reflexos que o uso inadequado de informações genéticas tem o condão de trazer para a sociedade como um todo.

Não se pode ter como pretensão reflexiva refutar a importância da genética em observância às relações atuais, consoante a multiplicidade de contribuições que a mesma é capaz de fornecer. Pretende-se, no entanto, no que tange às relações laborais, conformar adequadamente o uso da informação de caráter genético à manutenção dos direitos que já estão nitidamente protegidos pelo comando constitucional.

Dessa forma, deve-se ter em conta tanto o consentimento do empregado, detentor do código genético a ser acessado, quanto a finalidade de tal acesso pelo empregador. Os fins do acesso ao DNA pretendido dispõem da propensão necessária para conciliar a legitimidade e a legalidade da conduta, tendo em vista não poder se aproximar, sob nenhum pretexto, de finalidades discriminatórias.

Acrescente-se, pela relevância, que o desejo ou a necessidade de acessar a informação genética de alguém não podem estar dissociados da informação clara sobre a finalidade de acessá-la. Dessa forma, compete ao empregador justificar ao empregado as motivações que fundamentam o acesso ao conteúdo do seu DNA nos casos descortinados nesta pesquisa, que envolvem profissões naturalmente arriscadas e, destarte, com demandas específicas.

Os limites capazes de conter o acesso e o uso da informação de natureza genética estão postos na Constituição Federal de 1988. A dignidade, enquanto dimensão ontológica da pessoa, comporta-se como um elemento limitador pré-normativo. Todos os seres humanos, simplesmente por terem nascido humanos, são dignos de serem protegidos de qualquer forma de discriminação. A intimidade e a igualdade, por seu turno, atuam como elementos normativos capazes de desautorizar práticas que apontem para horizontes segregacionistas ou discriminatórios. E todos esses parâmetros são plenamente aplicáveis às relações laborais, com o reforço das repercussões jurídicas e sociais que algum posicionamento em contrário pode gerar. 


\section{REFERÊNCIAS}

ALEXY, Robert. Teoria dos direitos fundamentais. Tradução Virgílio Afonso da Silva. 2. ed. São Paulo: Malheiros, 2011.

ALVARENGA, Rúbia Zanotelli de. Direitos da personalidade do trabalhador e poder empregatício. São Paulo: Ltr, 2013.

ARENDT, Hannah. A condição humana. Tradução Roberto Raposo. 12. ed. Rio de Janeiro: Forense Universitária, 2015.

BAUMAN, Zygmunt. Tempos líquidos. Tradução Carlos Alberto Medeiros. Rio de Janeiro: Zahar, 2007.

BRASIL. Lei $\mathbf{n}^{\circ}$ 9.029, de 13 de abril de 1995. Proíbe a exigência de atestados de gravidez e esterilização, e outras práticas discriminatórias, para efeitos admissionais ou de permanência da relação jurídica de trabalho, e dá outras providências. Brasília, DF: Presidência da República, 1995. Disponível em: http://www.planalto.gov.br/ccivil_03/leis/19029.htm. Acesso em: 10 jul. 2018.

BRASIL. [Constituição (1988)]. Constituição da República Federativa do Brasil de 1988. Brasília, DF: Presidência da República, 1988. Disponível em: http://www.planalto.gov.br/ ccivil_03/constituicao/constituicao.htm. Acesso em: 10 jul. 2018.

CASABONA, Carlos María Romeo. La genética y la biotecnologia en las fronteras del Derecho. Acta Bioethica, v. 8, n. 2, p. 283-297, 2002.

CASSAR, Vólia Bomfim. Princípios trabalhistas, novas profissões, globalização da economia e flexibilização das normas trabalhistas. Niterói, RJ: Impetus, 2010.

CUNHA JÚNIOR, Dirley. Curso de Direito Constitucional. 9. ed. Salvador: Juspodivm, 2015.

DELGADO, Mauricio Godinho. O poder empregatício. São Paulo: LTr, 1996.

GALLARDO, Mercedes Vidal. Riesgo genético y discriminación. Revista Derecho Genoma Humano, n. 33, p. 127-167, 2010.

GEDIEL, José Antônio Peres. A irrenunciabilidade a direitos da personalidade pelo trabalhador. In: SARLET, Ingo Wolfgang (org.). Constituição, Direitos Fundamentais e Direito Privado. Porto Alegre: Livraria do Advogado, 2010.

GUNTHER, Luiz Eduardo; PEREIRA, Cláudia Cristina. A discriminação genética no mercado de trabalho. Revista Unicuritiba, Curitiba, v. 17, n. 18, p. 168-184, 2017.

LIMA, Firmino Alves. Teoria da discriminação nas relações de trabalho. Rio de Janeiro: Elsevier, 2011. 
LIMA NETO, Francisco. O direito de não sofrer discriminação genética: uma nova expressão dos direitos da personalidade. Rio de Janeiro: Lumen Iuris, 2008.

LOPEZ, Manuel Carlos Palomeque. Direito do Trabalho e ideologia: meio século de formação ideológica do Direito do Trabalho espanhol (1873-1923). Coimbra: Almedina, 2001.

MACHADO, Sidnei. A noção de subordinação jurídica: uma perspectiva reconstrutiva. São Paulo: LTr, 2009.

MEIRELES, Edilton. Abuso do direito na relação de emprego. São Paulo: LTr, 2004.

MYSZCZUK, Ana Paula; MEIRELLES, Jussara Maria de Leal. Testes genéticos, eugenia e contrato do trabalho: análise à luz da declaração universal dos direitos humanos e do genoma humano e da constituição federal de 1988. In: CONGRESSO NACIONAL DO CONPEDI, 38., 2009, São Paulo. Anais [...]. São Paulo: Conpedi, 2009.

MONTANHANHA, Beatriz Cardoso. A dinâmica do poder nas relações de trabalho e os impactos sobre a dignidade humana. São Paulo: LTr, 2014.

NASCIMENTO, Nilson de Oliveira. Manual do poder diretivo do empregador. São Paulo: LTr, 2009.

OSSWALD, Walter. Diagnóstico genético e medicina predizente. Diagnóstico prénatal. In: ASCENSÃO, José de Oliveira (xoord.). Estudos de Direito da Bioética. Coimbra: Almedina, 2005.

OTERO, Juan María Martínez. La generalización de los test genéticos y su incidencia en los derechos fundamentales. Revista Europea de Derechos Fundamentales, v. 29, p. 235266, 2017.

PESSANHA, Vanessa Vieira. O dever fundamental do empregador de qualificar seus empregados. 2015. 200 f. Tese (Doutorado em Direito) - Universidade Federal da Bahia, Salvador, 2015. Disponível em: https://repositorio.ufba.br/ri/bitstream/ri/18751/1/VANESSA\%20VIEIRA\%20PESSANHA.pdf. Acesso em: 10 jul. 2018.

ROMITA, Arion Sayão. Direitos fundamentais nas relações de trabalho. 5. ed. São Paulo: LTr, 2014.

SARLET, Ingo Wolfgang. A eficácia dos direitos fundamentais: uma teoria dos direitos fundamentais na perspectiva constitucional. 12. ed. Porto Alegre: Livraria do Advogado, 2015. SEGRE, Marco; GATTÁS, Gilka Jorge Figaro; WUNSCH FILHO, Victor. Genética, biologia molecular e ética: as relações trabalho e saúde. Revista Ciência e Saúde coletiva, Rio de Janeiro, v. 7, n. 1, p. 159-167, 2002.

SOMBRA, Thiago Luís Santos. A eficácia dos direitos fundamentais nas relações privadas. 2. ed. São Paulo: Atlas, 2011.

UGAS, Alejandra. Gajardo. El consejo genético desde una perspectiva bioética personalista. 
Acta Bioethica, v. 13, n. 2, p. 176-180, 2007.

VIANA, Roberto Camilo Leles. Pode o empregador ter acesso à informação genética do trabalhador? São Paulo: LTr, 2013.

YUNTA, Eduardo Rodríguez; VALDEBENITO, Carolina; LOLAS, Fernando. El problema del manejo de la información genética en Latinoamerica. Disponível em: https://www. researchgate.net/publication/242085293. Acesso em: 7 jul. 2018.

ZAGALO-CARDOSO, José; ROLIM, Luisa. Aspectos psicossociais da medicina preditiva: revisão da literatura sobre testes de riscos genéticos. Psicologia, Saúde \& Doenças, v. 6 , n. 1, p. 3-34, 2005.

\section{NOTA}

O artigo "Relações laborais e limites jurídicos ao acesso e uso das informações genéticas do empregado" teve a participação conjunta das coautoras no tocante ao projeto e esboço inicial, divisão dos tópicos, escolha das referências, redação do artigo (elementos pré e pós-textuais feitos por ambas, bem como o terceiro tópico de desenvolvimento; primeiro tópico de desenvolvimento escrito por Ana Thereza Meirelles; segundo tópico de desenvolvimento redigido por Vanessa Pessanha) e aprovação da versão final do arquivo. A coautora Ana Thereza Meirelles realizou a revisão de ABNT e a coautora Vanessa Pessanha revisou o texto quanto aos aspectos linguísticos. 